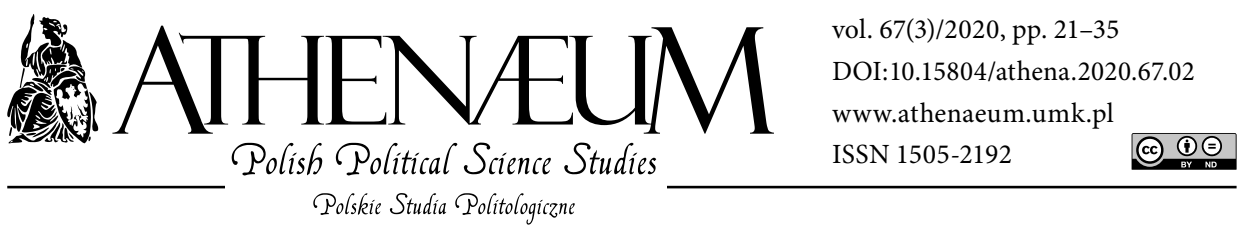

\title{
THE EVOLUTION OF THE EUROPEAN UNION URBAN AGENDA: A HARD PATH TOWARDS A CITY-ORIENTED POLICY?
}

\author{
EWOLUCJA AGENDY MIEJSKIEJ UNII EUROPEJSKIEJ: TRUDNA \\ DROGA DO POLITYKI MIEJSKIEJ?
}

\author{
Liliia Hrytsai*
}

\begin{abstract}
During the last decades, alongside the growing role of cities, the process of urbanization has been receiving more and more attention from the European policy-makers. This study analyzes the evolution of the EU urban agenda establishment

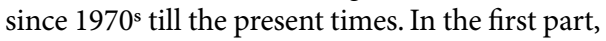
the paper presents five stages, most important milestones and core programs regarding the urbanization process in Europe. In the second section, the author pays a special attention to the Urban Agenda for the EU (the Pact of Amsterdam) as one of the key documents promoting the sound cooperation among the European urban policy stakeholders. In the final part, the paper provides the evaluation of the EU urban agenda's genesis by indicating the main features of this process.
\end{abstract}

Keywords: European Union; Urban Agenda for the EU; urbanization; cities
$\mathrm{W}$ ostatnich dziesięcioleciach, wraz z rosnącą rolą miast, proces urbanizacji cieszy się coraz większym zainteresowaniem europejskich decydentów. Niniejsze badanie analizuje ewolucję tworzenia agendy miejskiej UE od lat 70. XX wieku do czasów obecnych. W pierwszej części artykułu przedstawiono pięć etapów procesu urbanizacji w Europie, jego kamienie milowe oraz główne elementy programowe. W drugiej części autorka zwraca szczególną uwagę na Agendę Miejską dla UE (Pakt Amsterdamski) jako jeden z kluczowych dokumentów promujących solidną współpracę pomiędzy interesariuszami europejskiej polityki miejskiej. W końcowej części artykułu poddano ocenie przebieg tworzenia agendy miejskiej UE, z uwzględnieniem głównych cech tego procesu.

Słowa kluczowe: Unia Europejska; agenda miejska dla UE; urbanizacja; miasta

* Maria Curie-Skłodowska University in Lublin, Faculty of Political Science and Journalism. 


\section{INTRODUCTION}

Cities are important players in the European Union ${ }^{1}$ social, political and economic life. As of 2019, urban areas account for $75 \%$ of the total EU population. The level of urbanization varies from country to country - in Austria, it estimates only 59\%, while the Belgian urbanization reached $98 \%$ (World Bank, 2020). In comparison, globally the amount of people living in cities and towns amounts to $55 \%$ of the world population or 4.1 billion people (Ritchie \& Roser, 2018). Besides the urban areas occupy only $3 \%$ of the total Earth surface, they are responsible for $80 \%$ of global GDP, two-thirds of global energy consumption, 70\% of global waste and 75\% of global GHG emissions (REN21, 2019, p. 19). During the period of 2012-2016, the urban population growth in Europe estimated 2.4\%. The number of people living in the European cities and towns is expected to amount $83.7 \%$ in 2050 (European Commission, 2020).

At the beginning of 1970s, the European Community, instead of creation of the urban agenda, was focusing on cohesion and regional policies. Cities always have been sources of wealth, human capital and innovation, but at the same moment, they have been continuously facing a number of social, environmental and economic challenges, such as urban poverty, air and water pollution, high criminal rates, etc. The relevant regulations in the urban area were necessary at both supranational and national levels, but it took about three decades to initiate and then formalize the EU urban policy-making process. A range of informal ministerial meetings (1999-2016), a number of declarations adopted, three rounds of the URBACT program (2002-2006; 2006-2013; 2014-2020), and the Urban Agenda for EU (2016) constitute the main legacy and basis of the European urban policy-making. Nowadays, the urban dimension receives a special attention from the EU institutions, which support cooperation and knowledge exchange between local policy-makers and stakeholders (González Medina \& Fedeli, 2015, pp. 3-9).

The main aim of this article is to research the evolution of the EU urban policy, as well as to analyze and characterize this process from its beginning to the present time. Moreover, the author pays special attention to the Urban

1 The geographical scope of this research, first of all, encompasses the European Union, because the EU is presented here as a leader of the European urban policy-making. Nevertheless, the term 'Europe' is used here interchangeably, because many EU programs also contain non-EU Member States, such as Switzerland and Norway. 
Agenda for the EU (the Pact of Amsterdam), which takes a particular place in the EU urban policy-making. The paper aims to answer on the following three research questions: (1) What is the genesis of the EU urban policy-making? (2) How does the Urban Agenda for the EU support the urban dimension of European policy? (3) What are the most important features of the EU urban policy-making through decades? The research paper provides answers within three sections: the first one evaluates five stages and most important milestones of the European urban policy-making; the second section analyzes the Urban Agenda for the EU; the last part characterizes the evolution and present features of the European urban agenda.

The research method of this paper is based on a desk review of the topicrelevant scientific articles, i.e., González Medina \& Fedeli (2015), Parkinson (2005), and Olejnik (2017), as well as the EU strategic documents and declarations. The research material was supplemented by a number of official webpages with information of currently performed programs, the EU statistic databases, and the latest reports and guidelines provided by the EU. The received information from several diverse sources differs, thus the author compares, analyzes and presents her own vision of the evolution and main features of the EU urban policy-making.

\section{THE EVOLUTION OF THE EUROPEAN URBAN POLICY}

There is a lack of commonly accepted evolution stages of European urban policy-making. On the basis of a study conducted by Van den Berg et al. for the Dutch Presidency, Parkinson (2005) claims that the European urban policy development might be divided into the following four stages: Stage 1: 1975-1988; Stage 2: 1989-1993; Stage 3: 1994-1999; Stage 4: 2000-2006. According to the newest research presented by González Medina \& Fedeli (2015), the development of urban policy in Europe can be seen through four phases: Phase 1: 1990-1999; Phase 2: 2000-2006; Phase 3: 2007-2013; Phase 4: 2014-2020. Furthermore, there are various opinions regarding the formal beginning of the integration of urban dimension into the European policy. González Medina \& Fedeli (2015) argue that the Treaty of Rome (1958) became the first document which addressed the goal of "harmonious development" and thus entered the urban dimension into the debate. Olejnik (2017) believes that the first document presenting territorial and urban development to the European agenda was the Leipzig Charter on 
Sustainable European Cities (2007), which focuses on the involvement of the European stakeholders in the urban development policy. In turn, according to URBACT (2017), "Urban policy is not of itself an EU level responsibility [...] but in the Lisbon treaty of 2009, the notion of territorial cohesion appeared for the first time". Moreover, URBACT does not divide the European urban policy on a several stages or phases, but lists the most important milestones of the development of this policy. This section aims to specify the stages and investigate the most important milestones of the European urban policy.

The First Stage: 1975-1988. At this stage, González Medina \& Fedeli (2015) consider cities as the main sources of unbalances and socio-economic disparities both at a national level and between Member States. From the beginning it became clear that urban areas were experiencing a significant decline due to the globalization and deindustrialization movements. Since the establishment of Monetary Union in 1969, cities started to be considered as key players to perform new integrated actions, where social, economic and spatial dimensions could be tightly interconnected. On the other hand, due to the growing territorial unbalances, Member States payed a special attention to the spatial dimension at a supranational level. Since the establishment of the Club of Rome and their prominent publication The Limits of Growth (1972), cities started to be considered as important players in the emerging environmental crisis. Parkinson (2005) stresses that at this period the European Union was focused on regions, not at cities. Starting from its beginning, the European Community aimed to achieve political integration through economic integration. In the mid-1970s, the Community discovered that the realization of this ambitious plan can be threatened by the large economic gap between the rich and poor regions. To overcome this challenge, the European Regional Development Fund (ERDF) was initiated in 1975 with 5\% of the Community budget. The Single European Act established the basis for an authentic EU cohesion policy aiming to overcome the impact of the single market on less developed areas. In 1987, when the Act went into force, regional policy amounted to about $20 \%$ of the total EU budget. Besides the fact that the $1980^{\text {s }}$ brought significant concerns regarding the differences between regions, there was no direct link to the urban dimension.

The Second Stage: 1989-1999. In the early 1970s, cities and local authorities were seeking for a stronger position and better consideration within Member States. In this aspect, urban areas were experiencing a new autonomy with the same limited capacities. Mayors of most important European cities demonstrated their interest in the European institutions through which they could make an 
impact on the European agenda and policies (European Union, 2011, pp.32-34). In this sense, the role of city networks was particularly important - the Eurocity manifesto (1989) stated that Europe is represented by its cities, thus there is a huge necessity to grant the urban areas with a greater responsibility for the EU development. In 1989, after the reform of Structural Funds and the revision of the Treaty of Rome (focused on social and economic cohesion), the European Union launched its very first urban initiative, i.e., the Urban Pilot Projects (1989-1994), which was followed by URBAN I Program (1994-1999; González Medina \& Fedeli, 2015, p. 6).

Furthermore, the early $1990^{\text {s }}$ were determined by a strong influence of the ideas and concerns raised at the United Nations Conference on Environment and Development in 1992, so-called Rio Summit (Dühr, Colomb, \& Nadin, 2010, pp. 10-11). The "Rio spirit" was supported by the Aalborg Charter (1994), where the "urban issue" was formulated in terms of the Sustainable Development concept. Such prospective was recognized by the Treaty of Amsterdam (1997) and was embodied in one of the EU objectives. The "Report on European Sustainable Cities" (1996) drew attention to the lack of coherent EU urban policy and the notable absence of the idea of European urban agenda (González Medina \& Fedeli, 2015, p. 6).

The second stage also was marked by the development of a very first European urban agenda. The EU communication "Towards an Urban Agenda in the European Union" (1997) set four goals to be achieved by the European urban agenda, namely (1) competitiveness and employment; (2) economic and social cohesion; (3) transport and trans-European networks; and (4) sustainable development and the quality of life in cities (Atkinson, 2001, pp. 386-388). A year later, the aforementioned objectives were confirmed and specified in the following EU document titled "Sustainable Urban Development in the European Union: A Framework for Action" (1998). This framework addressed the issue of an improved coordination and targeted community action towards urban problems. It was presented as four interlinked policy goals: (1) Strengthening economic prosperity and employment in towns and cities; (2) Promoting equality, social inclusion and regeneration in urban areas; (3) Protecting and improving the urban environment: towards local and global sustainability; and (4) Contributing to good urban governance and local empowerment (Parkinson, 2005, p. 12).

The Third Stage: 2000-2006. At this stage, the European Union continued the above-mentioned development of comprehensive EU urban policies. The lack of formal EU competences in the area of urban and regional development made 
this process strongly intergovernmental and participatory. Starting from 1999, the European Commission had been promoting informal meetings between ministers responsible for local issues and spatial planning. These meetings established a broad range of principles and agreements, which laid in the basis of the present EU urban policies. Table 1 demonstrates the most important informal meetings regarding the EU urban issues.

Table 1. Informal Meetings Regarding the EU Urban Issues

\begin{tabular}{|l|l|l|l|}
\hline Year & Place & Ministers responsible & Documents adopted \\
\hline $\mathbf{1 9 9 9}$ & Potsdam (DE) & Spatial Planning & $\begin{array}{l}\text { European Spatial Development } \\
\text { Perspective }\end{array}$ \\
\hline $\mathbf{2 0 0 0}$ & Lille (FR) & Urban Affairs & Lille Action Programme \\
\hline $\mathbf{2 0 0 4}$ & Rotterdam (NL) & Urban Affairs & Acquis URBAN \\
\hline $\mathbf{2 0 0 5}$ & Bristol (UK) & Sustainable Communities & Bristol Accord \\
\hline $\mathbf{2 0 0 7}$ & Leipzig (DE) & Urban Policy & $\begin{array}{l}\text { Leipzig Charter on Sustainable } \\
\text { European Cities }\end{array}$ \\
\hline $\mathbf{2 0 0 7}$ & Leipzig (DE) & $\begin{array}{l}\text { Urban Development and } \\
\text { Territorial Cohesion }\end{array}$ & $\begin{array}{l}\text { Territorial Agenda of the European } \\
\text { Union }\end{array}$ \\
\hline $\mathbf{2 0 0 8}$ & Marseille (FR) & Urban Development & Marseille Declaration \\
\hline $\mathbf{2 0 1 0}$ & Toledo (ES) & Urban Development & Toledo Declaration \\
\hline $\mathbf{2 0 1 1}$ & Gödöllö (HU) & $\begin{array}{l}\text { Spatial Planning and Territorial } \\
\text { Development }\end{array}$ & $\begin{array}{l}\text { Territorial Agenda of the European } \\
\text { Union 2020 }\end{array}$ \\
\hline $\mathbf{2 0 1 4}$ & Athens (GR) & Cohesion Policy & $\begin{array}{l}\text { Towards an EU urban agenda - } \\
\text { future steps }\end{array}$ \\
\hline $\mathbf{2 0 1 5}$ & Riga (LV) & $\begin{array}{l}\text { Territorial Cohesion and Urban } \\
\text { Matters }\end{array}$ & $\begin{array}{l}\text { Riga Declaration } \\
\text { Matters }\end{array}$ \\
\hline $\mathbf{2 0 1 6}$ & Amsterdam (NL) & Amsterdam Pact \\
\hline
\end{tabular}

Source: González Medina \& Fedeli, 2015, p. 7.

At the first meeting held in Potsdam (Germany) in 1999, the ministers responsible for spatial planning launched the European Spatial Development Perspective (ESDP), which promoted a sustainable and balanced territorial development of the EU. This document set three main objectives: (1) economic and social cohesion; (2) sustainable development; and (3) balanced competitiveness of the European territory. Moreover, they proposed a new method supporting both analysis and coordination of the particular EU urban policies, as well as 
provided a common framework for debates about urban issue on the European scale (Atkinson, 2001). Nevertheless, the area of territorial development and sustainable development were overlapping, because both policy institutions were dealing with the same problems and objectives. This challenge finds its solution during the further stages of the EU urban agenda development process by merging into the cohesion policy framework (González Medina \& Fedeli, 2015, p. 8).

The European Council set the Lisbon Strategy 2000-2010, which defined the EU political context. This ten-year strategy aimed to promote the EU as "the most competitive and dynamic knowledge-based economy in the world, capable of sustainable economic growth, with more and better jobs and greater social cohesion" (European Commission, 2007). The Gothenburg Strategy (2001) complemented this objective by environment and sustainable development dimensions. Both documents strengthened the discourse regarding the leading role of cities in the EU economic growth, social cohesion and sustainable development. Both strategies were supported by the first pilot initiative - URBACT I program (2002-2006). This program gathered 118 cities across Europe and allocated more than EUR 900 million from the EU funding for urban-related targets (Dühr et al., 2010, p. 287).

The Forth Stage: 2007-2013. This period was marked by a complete integration of urban dimension in the EU policies. In 2007, the Informal Meeting of Ministers responsible for Urban Development and Territorial Cohesion in Leipzig (Germany) caused a new impulse for the development of the EU urban policies (European Union, 2007). Consequently, both the Leipzig Charter and the Territorial Agenda of the EU were adopted the same year. This was a clear sign of the growing interconnections between the urban dimension and the territorial approach of the EU policies within the framework of cohesion policy (Olejnik, 2017, pp. 175-175).

The Europe 2020 Strategy (2010) and the Treaty of Lisbon (2009) only underlined the role of urban areas in the prospective development of the EU, as well as pointed out that both fields require a high level of coordination. However, the notion of territorial cohesion was not clearly defined, as well as shared competences between Member States and the EU. This new status enabled the European Commission to overcome its historic limit regarding the formal competences in the field of urban development by authorizing the EC to intervene in the urban development issues (European Commission, 2014). Simultaneously, the technical field of the territorial and urban development began to be linked to territorial cohesion. This position was approved by the Toledo Declaration (2010) 
stating that the "urban development should be an integral part of the concept and wider context of territorial cohesion" (European Union, 2010). From the EU Structural Funds perspective this meant that urban policies would no longer be considered as Community Initiatives, but entirely integrated into national and regional Operational Programmes, mainly the National Strategic Reference Framework (NSRF). Additionally, majority of these changes was contextualized into the reflection process "Cities of Tomorrow" (2009) initiated by Johannes Hahn - the then Commissioner for Regional Policy. In 2011, as a result of this process, an expert report approved the existence of the "European model of urban development" (González Medina \& Fedeli, 2015, p. 10).

In 2007, the EC launched the second round of URBACT (2007-2013) covering the whole EU, Norway, and Switzerland (European Commission, 2007). The main aim of URBACT II was the promotion of cooperation and knowledge exchange between European cities. The initiative consisted of 70 programs covering 2.2 million inhabitants (URBACT II, 2011). The total budget of the program was estimated at EUR 67.8 million, from which $78.6 \%$ or EUR 53.1 million constituted sources from the European Regional Development Fund (ERDF; European Commission, 2007).

The Fifth Stage: 2014-2020. During this period the process of formalization of the EU urban agenda reached its peak. The present stage is characterized by a range of changes towards the formalization of the urban agenda both at EU and Member State level. First of all, the $1^{\text {st }}$ CITIES Forum in 2014 demonstrated a strong need for the EU urban agenda for various stakeholders across the Europe. In 2014, the European Commission launched a public consultation to improve the understanding of the EU urban agenda. The European Commission pointed that the main objective of this consultation is to reach relevant stakeholders from different levels and to gather their opinions of the further directions of the EU urban agenda. In 2015, the results of this consultation were presented at the $2^{\text {nd }}$ CITIES Forum, as well as summarized in the EC working document entitled "Results of the Public Consultation on the key Features of an EU Urban Agenda” (2015; González Medina \& Fedeli, 2015, p. 11).

Presented in 2014, the Integrated Sustainable Urban Development (ISUD) approach shifts from being "optional" to being "mandatory" in order to access to the European Regional Development Funding. According to Art. 7 of ERDF Regulation, "at least 5\% of the ERDF resources [...] shall be allocated to integrated actions for sustainable urban development where cities, sub-regional or local bodies [are] responsible for implementing sustainable urban strategies". The new 
rules and legislation regarding the next round of EU cohesion policy contained a more holistic approach and integrated sustainable urban strategies. Moreover, some Member States expressed their desire to launch their own national urban agendas within the frame of the new cohesion policy in accordance with the principles of the ISUD model (European Commission, 2014, pp. 1-4).

Following the URBACT I and II programs, URBACT III (2014-2020) aims to support the implementation of the Europe 2020 strategy through the promotion of integrated urban development. Being the instrument of the cohesion policy, URBACT III is co-financed by the European Regional Development Fund, the 28 EU Member States, Switzerland, and Norway. The budget of the third round estimates EUR 96.3 million. The main objective of actual program is the improvement of city capacities to manage sustainable urban policies and practices in a participative and integrated way. The program is mainly delivered through a transnational exchange of knowledge between practitioners and decision-makers at a local level (URBACT, 2020). According to the URBACT III Citizen's Summary concluding activities of URBACT in 2018, 205 cities have launched their own Integrated Action plans; over $90 \%$ of these plans are already approved by the municipalities; by September, $50 \%$ of cities had secured funds for their implementation; and by October, $80 \%$ had started to implement these actions (URBACT, 2018, p. 1).

\section{THE URBAN AGENDA FOR THE EUROPEAN UNION}

A special place in the EU urban policy-making is devoted to the Urban Agenda for the EU (the Pact of Amsterdam). This document was adopted on May 30, 2016, during the informal meeting of EU ministers responsible for urban development. The Dutch Presidency launched the Agenda as a political and strategical document mapping directions of the EU urban policy. Consultations regarding the draft of the Agenda began in the early 2016 and involved a broad range of multiple actors, including the European Commission, EU Member States, CEMR, EESC, EIB, CoR, EUKN, URBACT, Eurocities, and ESPON. The Agenda contains a number of important guidelines, i.e., operational frameworks, thematic priorities, objectives and actions (European Commission, 2019, p. 6).

The Pact of Amsterdam establishes a new model for multidimensional and multilevel cooperation of urban policy stakeholders aiming to strengthen the urban aspect in the EU policies. The Leipzig Charter (2007) and Toledo Declara- 
tion (2010) constitute the main foundation of the Agenda. Directorate-General for Regional and Urban Policy performs the function of coordinative body of the Agenda. The main tasks of DG are the following: (1) to ensure effectiveness and transparency of actions; (2) to monitor progress; (3) to prepare informal guidelines for the further development of the Pact; (4) to share feedback concerning Action Plans for Partnerships; and (5) to make evaluation of thematic priorities (European Union, 2016, pp. 6-7).

The implementation mechanism of the Agenda is based on cooperation within 4 Partnerships of the following stakeholders: Member States, the European Commission DGs, local governments, institutions and experts. The main aim of Partnerships is a multidimensional and multilevel reinforcement of the European urban policy in the following three areas: (1) better exchange of knowledge; (2) better regulation; and (3) better funding. Each priority area is delivered within a chosen Partnership aiming to prepare and realize the Action Plan in two or three years (Olejnik, 2017, pp. 177-179).

The Urban Agenda for the EU highlights 14 thematic priorities within 4 Partnerships:

1. Amsterdam Partnerships (2016):
a. Air quality;
b. Housing;
c. Urban poverty;
d. Inclusion of migrants and refugees;

2. Bratislava Partnerships (2017):
a. Digital transition;
b. Urban mobility;
c. Circular economy;
d. Jobs and skills in the local economy;

3. Malta Partnerships (2018):

a. Public procurement;

b. Sustainable use of land;

c. Energy transition;

d. Climate adaptation;

4. Vienna Partnerships (2019):

a. Security in public spaces;

b. Culture/cultural heritage (European Commission, 2019, p. 8).

14 Partnerships gather together 23 Member States, 10 regions, 96 cities and/or metropolitan regions, the 17 European Commission DGs and about 33 institu- 
tions, including European umbrella organizations, programs and networks, as well as private companies and civil society organizations. Totally, around 262 partners work together, facilitating the EU urban agenda through the regular dialogue and joined-up solutions. One of the most important characteristics of the Agenda is its capacity to connect policy actors who would otherwise not be linked. The cooperation and activities provided under this Agenda are funded through URBACT III and the Urban Innovative Actions (European Commission, 2019, p. 7).

\section{CHARACTERISTICS OF THE EU URBAN POLICY-MAKING}

Over a long time, the process of the EU urban policy-making has been informal and "implicit" in its nature. It was the consequence of the fact that the European Union had no formal competences in the area of urban development and spatial planning in that time. In 1992, the European Commission proposed to introduce some changes in the Maastricht Treaty in order to delegate to the EU a range of related competences, but Member States rejected this initiative. As the result, the European urban agenda has been created in the form of intergovernmental dialogue. Thus, since 1999, ministers responsible for urban development set periodically informal meetings, i.e., Potsdam, 1999; Lille, 2000; Rotterdam, 2004; Bristol, 2005; Leipzig, 2007; Marseille, 2008; Toledo, 2010; Gödöllö, 2011; Athens, 2014; Riga, 2015; and Amsterdam, 2016 (European Commission, 2019).

A list of amendments was introduced in 2012, which, on the one hand, improved the visibility of urban dimension in the EU agenda and, on the other hand, facilitated the integration between sustainable development and territorial communities within the cohesion policy. First of all, the former DG REGIO became the Directorate-General for Regional and Urban Policy, which undoubtedly underlined the presence of urban dimension in the EU policy. As it was recommended in the Toledo Declaration (2010), the urban development had been gradually integrated into the "territorial cohesion" objective. Furthermore, according to the Lisbon Treaty (2007), the "territorial cohesion" became a shared competence between the European Union and Member States. Secondly, since 2012 the Urban Development Group (1999) and the Network of Territorial Cohesion Contact Points (2007) share the same working webpage. Both initiatives provide technical reports for the informal meetings of ministers responsible 
for urban development and spatial development (González Medina \& Fedeli, 2015, p. 4).

The informal approach of the European urban policy-making required a participation of a broad range of urban actors and stakeholders. Besides of ministers responsible, the following actors were involved in the EU urban agenda establishment: the European Commission, the URBAN Intergroup at the European Parliament, the Urban Development Group (UDG), the European Economic and Social Committee (EESC), the Committee of the Regions (CoR), and the European Investment Bank (EIB). This list was complemented by a number of interest groups, organizations and city networks (e.g., ICLEI, Eurocities, CEMR, etc.), as well as technical networks (URBACT, EUKN, ESPON, etc.). Moreover, URBACT and other exchange programmes helped to strengthen relationships between local governments and between local governments and EU institutions. Such exchange programs provided both cities and EU institutions with relevant knowledge, contacts, technical assistance and funding in order to overcome national and regional dependence (Parkinson, 2005, pp. 3-7).

Nowadays, as around three-fourth of the EU total population is living in cities and towns, the urban dimension became one of the most important issues of the EU agenda. González Medina \& Fedeli (2015) argue that the most common feature of the latest EU urban policy-making process is its Europeanization. The authors define the Europeanization as "processes of (a) construction (b) diffusion and (c) institutionalisation of formal and informal rules, procedures, policy paradigms [...] which are first defined and consolidated in the making of EU public policy and politics and then incorporated in the logic of domestic discourse [...]". In practice, it means that the EU directly addresses urban issues in its strategic documents, which provides a strategic roadmap for all Member States.

In opposition to the early stages of the EU urban agenda creation, the European Commission pays a particular attention to the urban area and local policies. The urban Europeanization process is tightly connected to the ISUD approach, which is strongly promoted by the new Cohesion policy 2014-2020 through the European Structural and Investment Funds 2014-2020 (ESI Funds). Nowadays, the European Union provides Member States with the integrated financial instruments supporting urban development. Member States are encouraged to broadly use the financial tools facilitating sustainable urban development. Thus, a minimum of 5\% of the European Regional Development Funds resources should be invested in the realization of ISUD Strategies aiming to ensure a long- 
lasting improvement in the social, environmental and economic condition of cities (European Commission, 2019).

The actual process of Europeanization strongly facilitates the local empowerment and networking. At the same time, this process is strongly supported by the European Commission, which provides funding for the local initiatives, as well as promotes cooperation between Member State’s cities and towns. González Medina \& Fedeli (2015) distinguish three main dimensions of the current stage of the EU urban policy-making and its Europeanization. The first one is a topdown approach, which suggests that the implementation of the EU documents particularly concentrates on the domestic features and needs. The second, bottom-up dimension, points on the growing role of the local governments in the European policy-making. The third one, a horizontal approach, claims that the Europeanization can take place even without the direct involvement of EU institutions, however, the EU bodies can act as facilitators of the process by creating common platforms and networks for city cooperation.

\section{CONCLUSION}

The European urban agenda has been evolving through decades from being invisible to the top position within the EU policies. The research presents the evolution of the EU urban policy-making as five stages with a number of important milestones. At the first stage (1975-1988), the urban policy was not formalized, thus regions, but not cities, were gaining all the attention from EU policy-makers. The second stage activities (1989-1999) were marked by the first successful attempts to formally introduce the urban dimension into the EU policy-making and, in the result, the creation of the Urban Pilot Projects (1989-1994) and URBAN I Program (1994-1999). The third stage (2000-2006) of the EU policy-making was dominated by the informal meetings of ministers responsible, as well as the establishment of URBACT I (2002-2006). At the fourth stage (2007-2013), the EU urban policy-making was already formalized and put on a high level of the EU agenda; following URBACT I, the second round of this program was established for the period of 2007-2013. For the fifth stage (2014-2020), the European policy-makers presented the Integrated Sustainable Urban Development (ISUD) as a requirement to access the European Regional Development Funding; also, they continued URBACT initiative for the third round (2014-2020; URBACT, 2017). 
Established in 2016, the Urban Agenda for the EU (the Pact of Amsterdam) created 14 Partnerships aiming to promote a new model of multidimensional and multilevel cooperation between urban policy stakeholders. The 14 Partnerships cover major urban policy issues, such as air quality, urban mobility, energy transition, security in public spaces, etc. The Agenda enables local communities to improve the exchange of knowledge, regulations and funding. Nowadays, the Agenda is bringing together 262 participants from 96 cities and 10 regions in 23 Member States.

The EU urban policy-making has passed the path from being the informal area of the EU agenda to the well-developed European policy based on a broad range of strategic documents. During the "informal" period, the EU urban policy-making was mainly based on meetings of ministers responsible for local issues and spatial planning. A number of declarations was adopted during such meeting, i.e., the Leipzig Charter (2007), the Toledo Declaration (2010), and the above-mentioned Pact of Amsterdam (2016). The informal nature of the EU urban agenda required a high level of cooperation among various stakeholders including the EC, EESC, CoR, ICLEI, Eurocities, URBACT, and the private sector. After the formalization of the EU urban policy, the Europeanization took place. The European Union, particularly the EC, pays special attention to the European urban issues by creating three generations of the URBACT program and integrating the urban dimension into the EU cohesion policy. The EU financially supports urban-related projects through the European Regional Development Funds and promotes sustainable development of European cities with the Integrated Sustainable Urban Development approach.

\section{ReFERENCES:}

Atkinson, R. (2001). The Emerging "Urban Agenda" and the European Spatial Development Perspective: Towards an EU Urban Policy? European Planning Studies, 9(3), 385-406. DOI: 10.1080/09654310120037630.

Dühr, S., Colomb, C., \& Nadin, V. (2010). European Spatial Planning and Territorial Cooperation. London: Routledge. DOI: 10.4324/9780203895290.

European Commission (2007). Operational Programme "URBACT II". Retrieved from: https://ec.europa.eu/regional_policy/en/atlas/programmes/2007-2013/crossborder/ operational-programme-urbact-ii.

European Commission (2014). Integrated Sustainable Urban Development: Cohesion Policy 2014-2020. Retrieved from: https://ec.europa.eu/regional_policy/sources/ docgener/informat/2014/urban_en.pdf. 
European Commission (2019). Urban Agenda for the EU: Multi-Level Governance in Action. Retrieved from: https://ec.europa.eu/regional_policy/sources/docgener/ brochure/urban_agenda_eu_en.pdf.

European Commission (2020). Developments and Forecasts on Continuing Urbanisation: Urban Population. Retrieved from: https://ec.europa.eu/knowledge4policy/foresight/ topic/continuing-urbanisation/developments-and-forecasts-on-continuingurbanisation_en.

European Union (2007). Leipzig Charter on Sustainable European Cities. Retrieved from: https:/ec.europa.eu/regional_policy/archive/themes/urban/leipzig_charter.pdf.

European Union (2010). Toledo Informal Ministerial Meeting on Urban Development Declaration. Retrieved from: https://www.ccre.org/docs/2010_06_04_toledo_declaration_final.pdf.

European Union (2011). Cities of Tomorrow: Challenges, Visions, Ways Forward. Retrieved from: https://ec.europa.eu/regional_policy/sources/docgener/studies/ pdf/citiesoftomorrow/citiesoftomorrow_final.pdf.

European Union (2016). Establishing the Urban Agenda for the EU: 'Pact of Amsterdam'. Retrieved from: https://ec.europa.eu/regional_policy/sources/policy/themes/urbandevelopment/agenda/pact-of-amsterdam.pdf.

González Medina M., \& Fedeli, V. (2015). Exploring European Urban Policy: Towards an EU-National Urban Agenda? Gestión y Análisis de Políticas Públicas, 14(14), 7-22. DOI: 10.24965 /gapp.v0i14.10287.

Olejnik, A. (2017). Future Perspectives of the Implementation of EU Urban Agenda. International Studies. Interdisciplinary Political and Cultural Journal, 19(1), 175-188. DOI: 10.1515/ipcj-2017-0011.

Parkinson, M. (2005). Urban Policy in Europe: Where Have We Been and Where Are We Going? (Draft). NODE Project on European Metropolitan Governance for Austrian Federal Ministry of Education, Science \& Culture. Retrieved from: https:// www.researchgate.net/publication/268354377_URBAN_POLICY_IN_EUROPE_ WHERE_HAVE_WE_BEEN_AND_WHERE_ARE_WE_GOING_Draft.

REN21 (2019). Renewables in Cities: 2019 Global Status Report. Retrieved from: https:// www.ren21.net/wp-content/uploads/2019/05/REC-2019-GSR_Full_Report_web. pdf.

Ritchie, H., \& Roser, M. (2018). Urbanization. Our World in Data. Retrieved from: https:// ourworldindata.org/urbanization.

URBACT (2017). A Rough Guide to European Urban Policy. Retrieved from: https:// urbact.eu/rough-guide-european-urban-policy.

URBACT (2018). Citizen's Summary. Retrieved from: https://urbact.eu/sites/default/files/ layout-citizens_summary.pdf.

URBACT (2020). URBACT at a Glance. Retrieved from: https://urbact.eu/urbact-glance.

URBACT II (2011). URBACT Project Results. Retrieved from: https://urbact.eu/sites/ default/files/import/general_library/Rapport_Urbact_II.pdf.

World Bank (2020). Urban Population (\% of Total Population) - European Union. Retrieved from: https://data.worldbank.org/indicator/SP.URB.TOTL.IN.ZS?locations=EU. 